\title{
РЕФОРМИРОВАНИЕ АГРАРНЫХ ОТНОШЕНИЙ В ПРОЦЕССЕ РЫНОЧНОЙ ТРАНСФОРМАЦИИ БЕЛОРУССКОЙ ЭКОНОМИКИ: ПУТИ СТАНОВЛЕНИЯ И РЕЗУЛЬТАТЫ
}

\section{Л. Н. КРИВОШЕЕВА}

К.э.н., доцент кафедры «Экономическая теория»

УО «Белорусский торгово-экономический университет потребительской кооперации»

\section{Е. В. КРИЖАНОВСКАЯ}

Старший преподаватель кафедры «Экономическая теория»

УО «Белорусский торгово-экономический университет потребительской кооперации»

\section{М. Р. ЧЕРНЯВСКИЙ}

Старший преподаватель кафедры «Экономическая теория»

УО «Белорусский торгово-экономический университет потребительской кооперации»

\section{Аннотация}

Статья отражает историю становления аграрного реформирования, происходящего в экономике Республики Беларусь, начиная с 80-х годов, - до настоящего времени. Объектом исследования является реформирование аграрных отношений $u$, в частности, их центрального звена - земельных отномений, в прочессе рыночной трансформащии. Рассмотрены основные законодательные акты, принятые за время аграрного реформирования, направленные на эффективное использование земель, приносящее экономический, соииальный, экологический или иной полезньй результат.

\section{Abstract}

This article presents the history of the formation of the agrarian reform taking place in the economy of the Republic of Belarus, since the 80s,-until now. The object of the study is to reform agrarian relations and, in particular, their central link - land relations in the process of market transformation. The main legislative acts adopted during the agrarian reform, for the efficient use of land, producing economic, social, environmental or other useful result.

\section{ВВЕДЕНИЕ}

Наиважнейшим средством, позволяющим достигнуть удовлетворения возрастающих потребностей общества в сельскохозяйственной продукции, является рациональное использование земли. Чем бережнее общество будет относиться к земле, тем богаче оно будет, тем выше будет его благосостояние, тем больше будут удовлетворяться его жизненно необходимые потребности.

Общество на этапе перехода экономики к рыночным отношениям может осуществить дальнейший экономический и социальный прогресс только при более интенсивном поиске новых действенных форм и методов включения естественных процессов образования почвенного 
плодородия в экономический процесс воспроизводства.

Для Республики Беларусь процесс трансформации представляет собой коренное преобразование всей системы производительных сил и производственных отношений. Система производственных отношений, начиная с середины 80-х годов по настоящее время, требовала коренных изменений, связанных, прежде всего, со сменой форм собственности на средства производства. Аграрные отношения, являющиеся подсистемой производственных отношений общества, также потребовали перемен. Цель предлагаемой статьи заключается в анализе проблем становления, реформирования и функционирования механизма государственного и рыночного секторов аграрной экономики. В мировой и отечественной литературе ученые уделяли и уделяют внимание переходным процессам, происходящим в экономике в целом, а также, в её аграрном секторе. Данным вопросам уделено внимание в работах Б. Акбашева, С. Аукционека, В. Бондарева, В. Гусакова, Ж. Дебре, С. Комлева, Л. Кукреш, Р. Лукаса, Р. Нельсона, А. Никонова, С. Уинтера, М. Фридмена, М. Шапиро и других авторов. Однако, несмотря на внимание экономистов к данной проблеме, остаётся еще множество нерешенных задач, связанных с преобразовательными процессами в аграрном секторе экономики, решение которых должно послужить повышению экономического плодородия земли.

\section{РЕЗУЛЬТАТЫ И ИХ ОБСУЖДЕНИЕ}

Мировой опыт - убедительное свидетельство неоспоримых преимуществ рыночных методов хозяйствования. Однако мировой опыт также наглядно свидетельствует и о том, что кризис социально-экономической системы в условиях, когда составной его частью становится структурный кризис, ведет к торможению реформ переходного периода экономики, повышению инфляционных процессов, дефициту государственного бюджета, дестабилизации на микро- и макроэкономическом уровнях. Дестабилизирующие процессы постепенно могут захватить экономику в целом, включая и аграрный сектор.

В мировой литературе выделены четыре теории аграрных кризисов:

- теория «отражения» аграрных кризисов от промышленных;

- теория представления аграрных кризисов как составной части циклических кризисов производства;

- теория «перманентного» аграрного кризиса;

- теория длительных самостоятельных кризисов.

Можно предположить, что все теории нашли свое место в аграрном кризисе, охватившем в 90-е годы XX столетия Республику Беларусь. Обычно кризисное падение производства связано с недостатком спроса либо с ростом издержек, но возможен и принципиально иной тип кризисного механизма, вызванный сменой целевой функции производителей, независимо от спроса и предложения. И такое кризисное состояние было характерно для экономики Беларуси данного периода. С. Аукционек приводит пример подобного явления: «Сложился весьма специфический тип производителя - производителя, который, оказавшись в почти рыночной среде, преследует не 
вполне рыночные цели (в их традиционном понимании). Речь идет о десятках тысяч бывших государственных предприятий, для которых увеличение прибыли не стало первоочередной задачей. А главное для них - сохранить размеры предприятия, объёмы выпуска, финансирования, численность занятых». [1]

Убыточные сельскохозяйственные предприятия продолжали функционировать, так как их остановка могла вызвать увеличение издержек, которые превысили бы убытки неэффективного производства. Конкуренция же выправляет данную ситуацию только в долгосрочном периоде. Отсутствие ясной концепции и модели трансформации обернулось «переходным аграрным кризисом» для Беларуси.

Экономика, лишенная внутренних стимулов развития, имеющая неразвитость институтов рынка, а, следовательно, и слабый самонастраивающийся механизм, требовала, прежде всего, четкой конкретизации цели и модели экономического развития, опирающейся на теоретические разработки и опыт более развитых стран, либо стран, успешно проводящих подобные экономические реформы. Аграрная реформа, являющаяся лишь частью трансформационных процессов, происходящих в национальной экономике, должна органично вплетаться в процесс общего реформирования; причем обязателен выбор пути проведения аграрной реформы в целом и земельной реформы в частности. Поэтому из ряда имеющихся разработок по теории переходного периода надо было выбрать наиболее приемлемый вариант, обладающий неординарностью идеи и достаточной аргументацией.

Экономике переходного периода уделено достаточно внимания в мировой науке. К примеру, представители формалистической неоклассической теории «большого удара» Ж. Дебре и Р. Лукас считают главным в переходном процессе либерализацию цен, приводящую к микроэкономической реструктуризации и, в конечном счете, к формированию необходимой данному обществу структуры производства. Экономисты, придерживающиеся посткейнсианских взглядов и являющиеся в какой-то степени сторонниками теории «большого удара», все же предостерегают от поспешности в проведении реформ и рекомендуют активное вмешательство государства в финансовую сферу.

Представители эволюционной экономической теории, опирающиеся на теорию экономического развития Й. Шумпетера, придерживаются микроподхода, когда главенствующими считаются преобразовательные процессы на уровне фирм, которые Р. Нельсон и С. Уинтер назвали «рутинами». Эта теория схожа с теорией естественного отбора Ч. Дарвина: в процессе реформирования выживает сильнейший, отказавшийся от «рутины», но не потерявший капитал, а возместивший потери и получивший прибыль.

Проблемами переходного периода экономики занимаются также исследователи «эмпирического направления»: М. Фридмен, Ф. Модильяни, Дж. Тобин, экономисты Международного валютного фонда (МВФ). Эксперты МВФ выделяют три основных подхода к реформированию:

- шоковая терапия; 
- неинфляционный градуализм (постепенный переход с относительно небольшим уровнем инфляции);

- инфляционный градуализм.

На основании анализа реформ в различных странах с переходной экономикой эксперты МВФ пришли к выводу: чем решительнее и быстрее проводились реформы, тем быстрее преодолевались кризисные явления. К примеру, Польша, Чехия, Словения, Эстония, Латвия, проводившие «шоковую терапию» в девяностых годах, преодолели экономический спад и сумели поднять темпы роста валового внутреннего продукта. Что касается Венгрии и Словакии, то эксперты МВФ отнесли их к группе стран неинфляционного градуализма. Там также в течение первых 3-4 лет начала реформ удалось приостановить экономический спад. В Болгарии, России, Украине, отнесенных к группе стран инфляционного градуализма, тенденции к подъему ВВП за аналогичный период не наблюдались.

Иногда варианты перехода к рынку классифицируют следующим образом:

- затяжной;

- быстрый (включая «шоковую терапию»);

- промежуточные варианты (различные виды градуализма, т.е. постепенного перехода).

В принципе представленная классификация аналогична предыдущей. Республика Беларусь наряду с Украиной и Румынией была отнесена авторами данной классификации к странам с затяжным вариантом перехода к рынку. Исследователи выявили, что ВВП в стране быстрого реагирования на переход к рынку устойчиво растёт в первые 3-4 года реформ, а в стране с моделью затяжного характера снижается. Это относится и к доходам населения.

Что же касается аграрного реформирования, то оно не имело четкой теоретической модели, хотя и были представлены рекомендации по проведению аграрной реформы для стран СНГ, разработанные на основании исследований, проведенных в девяностых годах МВФ и Международным банком реконструкции и развития (МБРР), Организацией экономического сотрудничества и развития (ОЭСР), Европейским банком реконструкции и развития (ЕБРР) по решению глав и правительств «семерки». В результате исследований были представлены две модели реформирования АПК: консервативная и радикальная. Суть консервативной модели реформирования аграрного сектора экономики заключалась в ужесточении бюджетной политики, в корректировке цен, находящихся под государственным контролем в течение 3-5 лет, в проведении реформы медленными темпами. Радикальная модель основывалась на немедленной отмене контроля над основной массой цен, на приватизации предприятий, на ускоренном снижении бюджетного дефицита до уровня, не превышающего 2-3\% ВВП. Общая же стратегия данных двух моделей предполагала либерализацию цен, отмену госзаказов, сокращение государственной поддержки аграрного сектора, приватизацию сельскохозяйственных предприятий, роспуск колхозов и совхозов и создание на их основе ферм с полной частной собственностью на землю, а также реформирование кредитной системы. Обе эти модели поэлементно нашли применение: первая (консервативная) - в Узбекистане и Республике Беларусь, 
вторая (радикальная) - в России, Украине и Казахстане. Специфика развития экономики стран СНГ вносила поправки в предложенные модели.

На наш взгляд, лучшим вариантом перехода экономики к рыночным отношениям является двухсекторная модель. Сущность данной модели выражается в функционировании на определённом временном интервале «рыночного» и «государственного» секторов в экономике. Данная посылка находит подтверждение в работах таких известных зарубежных экономистов, как американского специалиста по экономике социалистических стран П. Мюррела, венгерских экономистов, занимающихся проблемами переходной экономики, Я. Корнаи и Ж. Келен, а также у некоторых ученых стран СНГ: Б. Акбашева, В. Белкина, В. Бондарева, А. Емельянова, С. Комлева, В. Могилевцева, и др. Что касается непосредственно аграрной реформы, то основой двухсекторной модели перехода к рынку является создание благоприятных условий для функционирования каждого из секторов переходной экономики. Как «государственный», так и «рыночный» секторы аграрной экономики в данной модели не должны использовать полумеры. Так, например, «рыночный» сектор должен иметь для своего существования весь комплекс рыночных элементов: свободные цены, оптовую торговлю, самостоятельные предприятия, конкурентную среду и т. п. Причем, поэлементный переход к рынку - сначала оптовая торговля, затем либерализация цен, экономическая свобода предприятий и т. д. - ведет к затягиванию движения реформы и искажает принципы деятельности рыночных субъектов. «Государственный» сектор аграрной экономики на протяжении некоторого времени также придерживается собственных методов управления, характерных для планово-командной экономики. В данном секторе некоторое время существует прежняя система ценообразования, сохраняется госзаказ, должны применяться административные методы балансирования спроса и предложения. «Государственный» и «рыночный» секторы устанавливают контакты между собой только через соответствующий орган (министерство). Некоторые экономисты (Д. Елисеев, В. Куликов) предлагали совместить «план» и «рынок» для вывода экономики из тупикового состояния. Они считали, что меры по кардинальному изменению положения должны были быть направлены главным образом на обеспечение государственного регулирования деятельности хозрасчетных предприятий, инициирования рыночного предпринимательства, но обязательно в рамках, гарантирующих плановое сбалансированное развитие народного хозяйства страны. К сожалению, в отечественной экономической науке проблеме несовместимости хозяйственных механизмов не уделялось должного внимания. Поэтому в экономике переходного периода прослеживались факты совмещения несовместимого. Так, Ф. Хайек утверждает, что и конкуренция, и централизованное руководство становятся плохими и неэффективными методами, если применяются не в полную силу: это разные средства решения одной и той же задачи, и смешение их приведет лишь к тому, что ни одно не окажется успешным и результат будет хуже, чем при последовательном применении чего-то одного. Именно поэтому очень важна была «чистота» функционирования экономического механизма государственного и рыночного секторов переходного периода аграрной экономики. В перестроечный период аграрной реформы, начиная со второй половины 
80-х годов, в сельскохозяйственное производство был внедрен внутрихозяйственный подряд во всем многообразии организационных и хозрасчетных форм, то есть в плановую экономику был внедрен атрибут рыночного хозяйства, что на первых порах дало положительный результат. Появилось множество теоретических разработок экономистов (Р.Н. Дорский, Н.А. Лаврушенко, А.И. Панченко, и др.), ратовавших за внедрение арендного подряда скорее на идеологической волне, чем на обоснованных теорией, а главное, практикой и временем выводах. Практика заставила остановить внедрение данных теоретических изысканий, поскольку избранный путь реформирования аграрного сектора экономики на селе себя не оправдал. Зависимость экономической выгоды от внедрения арендного подряда оказалась нелинейной. Чем дальше продвигалась аграрная реформа по данному пути от первоначального уровня применения подряда, тем меньший дополнительный эффект получали сельскохозяйственные производители. Этот пример подтверждает, что достижение цели требует эффективной научно обоснованной долгосрочной стратегии в проведении аграрной реформы, основанной на определенной теоретической модели перехода к рынку.

При использовании двухсекторной модели перехода к рынку предполагается пройти два этапа. На первом этапе переходного периода к рыночной экономике необходимо обеспечить «чистоту» функционирования каждого сектора. Самой сложной задачей этого этапа является создание высокоразвитого рыночного сектора. На втором этапе реформы должна произойти реструктуризация «государственного» сектора аграрной экономики; причем это должно произойти лишь в том случае, если «рыночный» сектор действительно эффективнее «планового». Эффект поэтапного внедрения двухсекторной модели реформирования аграрной экономики проявляется не сразу, он требует определенного периода времени и определенной корректировки данной модели по мере претворения в жизнь. На втором этапе реформы «государственный» сектор должен постепенно демонтироваться в государственное предпринимательство, которое поддерживает и стимулирует «рыночный» (частный) сектор, охватывая капиталоемкие и малоприбыльные звенья АПК, не имеющие возможности получения даже средней нормы прибыли. На данном этапе реформы, если двухсекторную модель применить в полной мере, «рыночный» сектор будет развиваться гораздо эффективнее «государственного». Конечным итогом данного процесса является стимулирование экономики в целом.

Нельзя не согласиться с мнением С. Комлева, который теоретически обоснованно утверждает, что при всех относительных преимуществах двухсекторной модели она останется (даже при самой успешной реализации) только «меньшим из зол», минимально болезненным вариантом перехода к рынку, отнюдь не избавляющим от неудобств и тягот, сопровождающих смену типологии хозяйства. Исследование вопросов аграрных преобразований усложняется тем, что отсутствуют логически выверенная системная концепция и стратегия развития аграрной реформы, а также четкое обозначение цели и инструментов её достижения. Так, в государственной программе реформирования АПК Республики Беларусь записано, что основная цель аграрной реформы определена как «обеспечение постепенного перехода в сфере агропромышленного 
производства от командно-административной к рыночной системе хозяйствования, предполагающей свободное функционирование хозяйствующих субъектов в рамках правового коридора при государственном регулировании отдельных сторон деятельности». [2]

С нашей точки зрения, переход к рыночной экономике является не целью реформы, а средством достижения главной стратегической цели, заключающейся в повышении благосостояния населения Беларуси и приближения его к жизненному уровню населения развитых стран. Этот вывод можно сделать на основании того, что аграрная политика, являющаяся частью общеэкономической политики страны, должна учитывать стратегическую цель реформирования национальной экономики в целом. В этих условиях усиливается роль правительства как органа, отвечающего за экономическую политику. Государство должно иметь конкретное представление, подтвержденное научными разработками, о целях и инструментах воздействия на них. Цели могут быть разбиты на ряд промежуточных. К промежуточным целям предъявляются определенные требования, например, они должны иметь достаточную степень измеримости и быструю реакцию на изменение инструмента. Через достижение промежуточных целей можно запланировать желаемый результат и проконтролировать движение к нему. Важнейшими инструментами, с помощью которых можно реализовать достижение оптимального уровня цели, являются экономические меры и законодательные акты и нормы. Ранее мы отмечали, что на первом этапе двухсекторной модели перехода к рыночной экономике самой сложной задачей является обеспечение и поддержка «чистоты» рыночного сектора. Данная чистота функционирования рыночных отношений в агропромышленном комплексе должна базироваться на правовых нормах, то есть защите прав собственности; законодательном регулировании взаимоотношений между потребителями, производителями и наемными работниками. Необходимо заметить, что в этой области сделано немало. Сюда можно отнести деятельность государства по защите конкуренции и борьбе с монополизмом, введение законодательных актов купли-продажи земли. Применение экономических мер также способствуют внедрению и усилению «рыночного» сектора в переходной экономике. К ним относятся меры по экономической стабилизации, предполагающие стимулирование расширенного воспроизводства аграрной продукции и плодородия почвы через налогообложение, ценообразование, правительственные расходы на поддержку реформирования аграрного сектора и т. д.

Реформирование экономики в своем развитии всегда должно иметь долгосрочные цели и методы их осуществления. Опираться же на текущую рыночную конъюнктуру - значит заранее обречь реформы на провал.

Стратегическая цель реформирования АПК предполагает претворение в жизнь целой системы промежуточных целей:

- разработку правового обеспечения всего комплекса рыночных преобразований;

- осуществление поэтапной либерализации всех форм экономической деятельности;

- обеспечение единого и равного подхода к имеющимся формам собственности;

- формирование системы надежной социальной защиты; 
- преобразование системы распределительных отношений;

- создание конкурентной среды и предотвращение недобросовестной деятельности субъектов хозяйствования на рынке;

- преобразование системы государственного регулирования социально-экономических процессов с переводом ее на экономические методы и сохранением прямого управления в тех сферах, где рыночная саморегуляция неэффективна;

- формирование финансовой кредитно-денежной системы, способной обеспечить социальноэкономическую эффективность функционирования и развития народного хозяйства;

- создание предпосылок ускоренного технического развития производства на основе полного использования собственного технического потенциала, импорта высоких технологий путем совершенствования механизма привлечения внутренних и внешних инвестиций в экономику АПК страны;

- проведение реструктуризации и коммерциализации государственных предприятий (с индивидуальным подходом к крупным предприятиям), усиление маркетинговой деятельности для эффективного завоевания и удержания рынков;

- обеспечение экономической и продовольственной безопасности страны;

- проведение земельной реформы;

- формирование структурной перестройки в агропромышленном комплексе и развитие рыночной инфраструктуры;

- реформирование системы управления агропромышленным комплексом;

- применение энерго- и ресурсосберегающих технологий.

При достижении конечной цели следует учитывать фактор времени и появление лага, вызванного замедлением проведения в жизнь экономических и правовых процессов. Игнорирование этих обстоятельств может привести к просчетам в предполагаемом временном интервале достижения конечного результата реформы. Временная структура аграрной реформы предполагает:

- лаг признания, т.е. время, необходимое для признания необходимости проведения реформы;

- лаг решения, т.е. время между признанием проблемы и принятием конкретного решения по ней, например, принятие законов, постановлений и т.д.;

- лаг реализации решений через практику, которая зависит от степени бюрократизации госаппарата;

- лаг воздействия, выражающийся во времени, необходимом для изменения текущих инструментов.

Так, например, происходят приватизационные процессы, изменяются земельные отношения, и только через годы аграрный сектор экономики в результате лага воздействия начинает функционировать в темпе расширенного воспроизводства плодородия почвы, являющегося, по нашему мнению, основой повышения благосостояния населения страны. 
Согласно лаговой структуре проведения аграрной реформы, непременно происходит вмешательство государства в экономическую систему. Причем, государственное вмешательство сначала довольно интенсивно влияет на скорость проведения реформы, затем наступает момент наивысшей точки эффекта. При дальнейшем вмешательстве в регулирование экономического процесса аграрной реформы возможен отрицательный эффект, который зачастую приводит к затуханию эффективности проводимого реформирования, к появлению побочных, незапланированных эффектов и даже к негативным результатам. Например, попытка правительства повысить рентабельность сельскохозяйственных предприятий может привести всего лишь к увеличению цен на ресурсы. Так было и с внедрением арендного подряда, который, достигнув апогея эффекта, затем стал давать отрицательные результаты и не оправдал возлагаемых на него надежд. Подобное наблюдалось и с теми колхозами и совхозами, где происходила лишь смена вывесок, формальная замена их на акционерные общества, при оставшихся на деле прежних формах хозяйствования. Здесь наблюдалось проявление экономикополитических противоречий, которые были вызваны недостаточной экономической экспертизой поставленной цели и подавлением государственными структурами движения к свободе новоявленных экономических структур. Поэтому для принятия конкретных мер в аграрной политике надо исходить из основных целей макроэкономической политики. Необходимость вмешательства государства в ход аграрной реформы должна диктоваться временным соотношением издержек государственного регулирования с теми выгодами, которое это вмешательство может принести. Поэтому каждый этап реформы должен быть рассчитан во времени и подкреплен применением научно обоснованных инструментов, влияющих на достижение конечной цели аграрной реформы.

Земля служит проводником созидательной деятельности людей в особой отрасли материального производства - земледелии и других отраслях сельского хозяйства, которое считается центральным звеном агропромышленного комплекса. В составе агропромышленного комплекса (АПК) выделяют три сферы:

1) отрасли, обеспечивающие средствами производства сельское хозяйство и промышленность, перерабатывающую сельскохозяйственное сырьё;

2) отрасли сельского, рыбного и лесного хозяйства;

3) отрасли и производства, занимающиеся заготовкой, хранением и переработкой сельскохозяйственного сырья.

В АПК входит также производственная и социальная инфраструктура. Объектом нашего исследования является реформирование аграрных отношений. В данном случае, наибольший интерес для нас представляет вторая сфера АПК. В связи с этим отметим, что все земли в Республике Беларусь делятся на категории и виды. Категория земель - это земли, выделяемые по основному целевому назначению и имеющие определенный законодательством правовой режим использования и охраны. Согласно Ст.6 Кодекса Республики Беларусь о земле, земли Республики Беларусь делятся на следующие категории: 
- земли сельскохозяйственного назначения;

- земли населенных пунктов, садоводческих товариществ, дачных кооперативов;

земли промышленности, транспорта, связи, энергетики, обороны и иного назначения;

земли природоохранного, оздоровительного, рекреационного, историко-культурного назначения;

- земли лесного фонда;

- земли водного фонда;

- земли запаса.

К землям сельскохозяйственного назначения относятся земельные участки, включающие в себя сельскохозяйственные и иные земли, предоставленные для ведения сельского хозяйства.

К землям населенных пунктов, садоводческих товариществ, дачных кооперативов относятся земли, земельные участки, расположенные в границах городов, поселков городского типа, сельских населенных пунктов, садоводческих товариществ, дачных кооперативов, за исключением земель, отнесенных к иным категориям в этих границах.

К землям промышленности, транспорта, связи, энергетики, обороны и иного назначения относятся земельные участки, предоставленные для размещения объектов промышленности, транспорта, связи, энергетики, размещения и постоянной дислокации государственных таможенных органов, воинских частей, военных учебных заведений и организаций Вооруженных Сил Республики Беларусь, других войск и воинских формирований Республики Беларусь, иных объектов.

К землям природоохранного назначения относятся земельные участки, предоставленные для размещения заповедников, национальных парков и заказников. К землям оздоровительного назначения относятся предоставленные земельные участки для размещения объектов санаторнокурортного лечения и оздоровления. К землям рекреационного назначения относятся земельные участки для размещения объектов, предназначенных для организованного массового отдыха населения и туризма. К землям историко-культурного назначения относятся земельные участки, предоставленные для размещения недвижимых материальных историко-культурных ценностей и археологических объектов.

К землям лесного фонда относятся лесные земли, а также нелесные земли, расположенные в границах лесного фонда, предоставленные для ведения лесного хозяйства.

К землям водного фонда относятся земли, занятые водными объектами, а также земельные участки, предоставленные для ведения водного хозяйства, в том числе для размещения водохозяйственных сооружений и устройств.

К землям запаса относятся земли, земельные участки, не отнесенные к иным категориям и не предоставленные землепользователям. Земли запаса находятся в ведении соответствующего исполнительного комитета, рассматриваются как резерв и могут использоваться после перевода их в иные категории земель. [3]

Что касается видов земель, то независимо от деления на категории земель, земли 
Республики Беларусь согласно Ст. 7 Кодекса Республики Беларусь о земле подразделяются на следующие виды:

- пахотные земли - сельскохозяйственные земли, систематически обрабатываемые (перепахиваемые) и используемые под посевы сельскохозяйственных культур, включая посевы многолетних трав со сроком пользования, предусмотренным схемой севооборота, а также выводные поля, участки закрытого грунта (парники, теплицы и оранжереи) и чистые пары;

- залежные земли - сельскохозяйственные земли, которые ранее использовались как пахотные и более одного года после уборки урожая не используются для посева сельскохозяйственных культур и не подготовлены под пар;

- земли под постоянными культурами - сельскохозяйственные земли, занятые искусственно созданной древесно-кустарниковой растительностью (насаждениями) или насаждениями травянистых многолетних растений, предназначенными для получения урожая плодов, продовольственного, технического и лекарственного растительного сырья, а также для озеленения;

- луговые земли - сельскохозяйственные земли, используемые преимущественно для возделывания луговых многолетних трав, земли, на которых создан искусственный травостой или проведены мероприятия по улучшению естественного травостоя (улучшенные луговые земли), а также земли, покрытые естественными луговыми травостоями (естественные луговые земли);

- лесные земли - земли лесного фонда, покрытые лесом, а также не покрытые лесом, но предназначенные для его восстановления (вырубки, гари, редины, пустыри, прогалины, погибшие древостои, площади, занятые питомниками, плантациями и несомкнувшимися лесными культурами, и др.), предоставленные для ведения лесного хозяйства;

- земли под древесно-кустарниковой растительностью (насаждениями) - земли, покрытые древесно-кустарниковой растительностью (насаждениями), не входящей в лесной фонд;

- земли под болотами - избыточно увлажненные земли, покрытые слоем торфа;

земли под водными объектами - земли, занятые сосредоточением природных вод на поверхности суши (реками, ручьями, родниками, озерами, водохранилищами, прудами, каналами и иными поверхностными водными объектами);

- земли под дорогами и иными транспортными коммуникациями - земли, занятые дорогами, просеками, прогонами, линейными сооружениями;

- земли общего пользования - земли, занятые улицами, проспектами, площадями, проездами, набережными, бульварами, скверами, парками и другими общественными местами;

- земли под застройкой - земли, занятые капитальными строениями (зданиями, сооружениями), а также земли, прилегающие к этим объектам и используемые для их обслуживания;

- нарушенные земли - земли, утратившие свои природно-исторические признаки, состояние и характер использования в результате вредного антропогенного воздействия и находящиеся в состоянии, исключающем их эффективное использование по исходному целевому назначению; 
- неиспользуемые земли - земли, не используемые в хозяйственной и иной деятельности;

- иные земли - земли, не отнесенные к видам земель. [4]

Земельные ресурсы включают все виды земель: сельскохозяйственного назначения, населенных пунктов, промышленности, транспорта, курортов, заповедников, государственного лесного фонда. Почвы в Республике Беларусь не отличаются богатым составом. В основном это дерново-подзолистые заболоченные почвы.

По данным Белстата, земельный фонд Республики Беларусь на начало 2013 года составляет 207,60 тыс. га. Сельскохозяйственные земли занимают 43\% (8897,5 тыс. га), из них пашня - 30\% общей площади. На душу населения приходится 0,9 га сельскохозяйственных земель, в том числе 0,6 га пашни. Неиспользуемые и слабо используемые земли в народном хозяйстве (пески, кустарники, болота и т.д.) составляют 15\% общей площади. За последние 20 лет из сельскохозяйственного оборота выбыло 488 тыс. га. Что касается структуры посевов, то по сравнению с 2000 годом (по данным Белстата - в хозяйствах всех категорий; в процентах к итогу) в 2012 году увеличились посевы кормовых культур на 7,1\%, картофеля на 4,9\%, овощей на 0,5\%, но уменьшились посевы зерновых и зернобобовых культур на 5,5\% и технических культур на $7 \%$.

Интересен тот факт, что в Беларуси преобладает городское население. Урбанизация характерна для многих развитых и развивающихся в экономическом плане стран мира. Что касается Республики Беларусь, то по данным Белстата по состоянию на 01.02.2013 г. более 76,3\% (7 млн. 252 тыс. человек) населения проживает в городах и только 23,7\% (2 млн. 210 тыс. человек) - сельские жители.

Пятая часть населения страны - живет в сельской местности. И, именно, сельскохозяйственный производитель, по данным Белстата - 2013г., обеспечивает население страны основными продуктами питания. [5]

Аграрные производственные отношения охватывают экономические отношения общества в сфере присвоения и использования земли и основных средств сельскохозяйственного производства, его продукции и доходов. Эпицентром всестороннего обновления аграрных отношений являются земельные отношения. Земельные отношения - отношения, связанные с созданием, изменением, прекращением существования земельных участков, возникновением, переходом, прекращением прав, ограничений прав на земельные участки, а также с использованием и охраной земель, земельных участков. То есть это отношения между различными экономическими субъектами по поводу присвоения, владения, пользования и распоряжения землей. Земельные участки могут находиться у землепользователей на следующих правах: государственной и частной собственности, а также на праве собственности иностранных государств, международных организаций; пожизненного наследуемого владения; постоянного пользования (пользования без заранее установленного срока); временного пользования; аренды (субаренды). Попадая в сферу производства, земля становится объектом присвоения, то есть собственностью. Возникновение отношений собственности на землю как на условие 
материального производства обусловливает экономический характер земельных отношений.

Субъектами земельных отношений выступают Президент Республики Беларусь, Совет Министров Республики Беларусь, государственные органы, осуществляющие государственное регулирование и управление в области использования и охраны земель, граждане Республики Беларусь, иностранные граждане и лица без гражданства, индивидуальные предприниматели, юридические лица Республики Беларусь, иностранные юридические лица и их представительства, иностранные государства, дипломатические представительства и консульские учреждения иностранных государств, международные организации и их представительства.

Объектами земельных отношений в аграрной сфере являются все используемые земли: земельные участки, их части, земельные доли, права на земельные участки, их части и доли, ограничения прав на земельные участки, в том числе земельные сервитуты. Земельный сервитут, согласно Ст.1 Кодекса Республики Беларусь о земле - это право ограниченного пользования чужим земельным участком, устанавливаемое для обеспечения прохода, проезда, прокладки и эксплуатации газопроводов, нефтепроводов, воздушных и кабельных линий электропередачи, связи и других подобных сооружений, обеспечения водоснабжения и мелиорации, размещения геодезических пунктов, а также для иных целей, которые не могут быть обеспечены без предоставления такого права. То есть объектами земельных отношений в сельском хозяйстве выступают сельскохозяйственные угодья и их составные части. [6]

Структурные элементы земельных отношений взаимосвязаны и взаимообусловлены. В современной экономической литературе по преобразованию земельных отношений многие авторы уделяют внимание лишь отдельным вопросам земельных отношений, не рассматривая проблему в комплексе, либо относят к земельным отношениям те отношения, которые не имеют в своей основе отношений земельной собственности. Комплексно подходят к рассмотрению земельных отношений ученые И. Н. Буздалов, Э.Н. Крылатых, А.А. Никонов, которые утверждают, что между субъектами земельных отношений возникают и развиваются правовые, экономические и организационные отношения в сфере владения, пользования и распоряжения землей и определяют в системе этих отношений три функциональные подсистемы:

- первая подсистема - это правовой базис земельной собственности, включая права владения, пользования и распоряжения землей; государственные гарантии сохранения и укрепления собственности; ответственность землевладельцев за рациональное использование земли;

- вторая подсистема - это экономический механизм регулирования земельных отношений, включая платность землепользования, нормативные и рыночные цены земельного оборота, экономические стимулы и санкции, обеспечивающие рациональное использование земельных угодий;

- третья подсистема - это организационная структура реализации земельных отношений, включающая представление и изъятие земель, землеустройство, проведение землеоценочных работ, зонирование территорий, осуществление земельного мониторинга, а также всю 
совокупность организаций, которые осуществляют эти функции». Соглашаясь в целом с содержанием первой и третьей подсистем, ставим под сомнение правильность второй, по нашему мнению, в ней допущена неточность. Платность землепользования, нормативные и рыночные цены земельного оборота, естественно, могут быть регуляторами земельных отношений, но не могут быть в таком случае подсистемой самих земельных отношений, поскольку относятся к финансовым отношениям. Вероятно, необходимо говорить о купле-продаже земли, а также о том, что земля должна иметь цену, подвергаться экономической оценке, что имеет большое значение для уяснения самой системы земельных отношений, так как земельный рынок является частью земельных отношений, основой которых являются как раз отношения собственности.

Считаем необходимым, остановиться на структуре земельных отношений, в которую входят: отношения между юридическими и физическими лицами, складывающиеся в процессе наделения их землей, в процессе купли-продажи земли, её аренды, залога, дарения, обмена, выделения земельного участка, использования земли в производственных целях, мониторинга земель. В этот комплекс отношений следует включить, с нашей точки зрения, и отношения, складывающиеся в процессе воспроизводства полезных свойств земли, и рентные отношения, поскольку, нельзя не согласиться с утверждением К. Маркса, что «присвоение» ренты есть «экономическая форма реализации земельной собственности». [7]

Все изменения, происходящие в земельных отношениях, должны опираться на научно разработанную правовую базу и претворяться в жизнь при помощи организационной структуры аграрного реформирования, включающей различные организации и учреждения, непосредственно занимающиеся регулированием земельных отношений (научно-исследовательские и проектные институты по земельным ресурсам, управления и отделы властных структур, землеустроительные организации). Основные принципы земельных отношений, согласно Ст. 5 Кодекса Республики Беларусь о земле осуществляются на основе:

- государственного регулирования и управления в области использования и охраны земель, в том числе установления единого порядка изъятия и предоставления земельных участков, перевода земель из одних категорий и видов в другие;

- обязательной государственной регистрации земельных участков, прав на них и сделок с ними;

- единства судьбы земельного участка и расположенных на нем капитальных строений (зданий, сооружений), если иное не предусмотрено Кодексом о земле и иными законодательными актами;

- использования земельных участков по целевому назначению;

- приоритета использования сельскохозяйственных земель сельскохозяйственного назначения, земель природоохранного, оздоровительного, рекреационного, историко-культурного назначения, лесных земель лесного фонда для целей, связанных с назначением этих земель;

- эффективного использования земель;

- охраны земель и улучшения их полезных свойств; 
- платности землепользования;

- установления ограничений прав на земельные участки, в том числе земельных сервитутов;

- гласности и учета общественного мнения при принятии решений об изъятии и предоставлении земельных участков, изменении их целевого назначения, установлении ограничений прав на земельные участки, в том числе земельных сервитутов, затрагивающих права и защищаемые законом интересы граждан;

- защиты прав землепользователей.

Что касается преобразования земельных отношений, то оно окончательно произойдёт только в том случае, если все составляющие земельных отношений будут подвергнуты глубокому реформированию. А это возможно осуществить через земельную реформу, которая имеет достаточно длительный период внедрения. Ученые Н. Д. Кондратьев и Н. П. Макаров в работе «О крупнокрестьянских хозяйствах» определили три условия рационального реформирования: вопервых, реформы должны быть реалистичными, выполнимыми и непременно осуществляться, вовторых, они должны приводить к повышению производительности или, по крайней мере, не приводить к понижению и, в-третьих, отвечать требованию справедливости.

Земельная реформа, проводимая в Республике Беларусь с 90-х годов по настоящее время, представляет собой процесс целенаправленного изменения системы земельных отношений. Постановлением Верховного Совета Республики Беларусь от 18 февраля 1991 г. «О проведении земельной реформы в республике» была определена задача реформы, которая заключалась в следующем: «...в перераспределении земель с целью создания условий равноправного развития различных форм хозяйствования на земле, формирования многоукладной экономики в аграрном секторе и достижения на этой основе стабильного наращивания производства сельскохозяйственной продукции». [8] Дело в том, что только на основании перечисленных мер достичь стабильного наращивания производства сельскохозяйственной продукции было бы просто невозможно, так как был не учтён важнейший момент сущностного порядка. Кроме перераспределения земли, развития различных форм хозяйствования и формирования многоукладной экономики, для выполнения задачи реформы необходимо достижение расширенного воспроизводства почвенного плодородия, поскольку именно на этой основе можно добиться стабильного производства сельскохозяйственной продукции. По нашему мнению, было допущено очень важное упущение в определении задачи земельной реформы. Уместно заметить, что известные белорусские ученые, такие, как Б. М. Шапиро и В. Г. Гусаков, отмечали, что земельная реформа - не простое перераспределение земли в связи с появлением новых форм собственности и хозяйствования, а сложный комплекс мер, призванных в совокупности достичь четырех основных целей:

- осуществить переход к многообразию форм собственности и хозяйствования на земле;

- обеспечить социально справедливое и экономически обоснованное перераспределение земель и создание равных условий для развития многоукладной экономики; 
- создать экономический механизм, направленный на регулирование земельных отношений, стимулирование рационального использования и охрану земель (платность землепользования, разрешение купли-продажи земли и др.);

- остановить деградацию земли.

Данное определение реформы и комплекс перечисленных мер были отражены в большинстве публикаций о земельной реформе переходного периода экономики (В. А. Дадалко, И. Н. Буздалов, Э. Н. Крылатых, Б. М. Шапиро и др.). Наша точка зрения во многом совпадает с мнением данных авторов, но имела и имеет некоторое принципиальное отличие, касающееся вопроса перехода к многообразию форм собственности. Мы считаем, что первая цель земельной реформы должна состоять в демонополизации государственной собственности и становлении института частной собственности. Кодексом Республики Беларусь о земле от 19 декабря 1998 года в законодательном порядке были установлены две формы земельной собственности: государственная и частная. Многообразными их назвать нельзя. Но вот формы использования земельной собственности в различных типах хозяйств и сельскохозяйственных предприятий, действительно, являются многообразными. Например, частная собственность в аграрном секторе функционирует в двух основных хозяйственных формах: 1) фермерские и личные подсобные хозяйства, 2) коллективно-долевая форма хозяйствования: акционерные общества, кооперативы, товарищества, артели и т.д.

Становление системы рыночных отношений в белорусской экономике привело к становлению земельных отношений рыночного типа. Если проследить их развитие за последние двадцать с лишним лет, то можно увидеть явный прогресс. Так, Кодекс о земле 1990 года закреплял земельные отношения, связанные с одной формой собственности на землю государственной. До введения в 1990 году Кодекса Республики Беларусь о земле в республике существовал лишь режим землепользования различных субъектов земельных отношений. С декабря 1990 года Кодексом о земле (Ст. 7), кроме землепользования, предусматривался режим пожизненного наследуемого владения землей гражданами республики и передача в постоянное владение землей колхозам, совхозам, другим государственным, кооперативным, общественным предприятиям, учреждениям и организациям, а в 1993 году в Законе «О праве собственности на землю» была признана и частная собственность на землю. Принятые за последние два десятка лет в Республике Беларусь основные законодательные акты, регулирующие земельные отношения: Кодекс Республики Беларусь о земле (11.12.1990г.), постановление «О проведении земельной реформы в республике» (18.02.1991г.), законы «О платежах за землю» (18.12.1991 г.), «О крестьянском (фермерском) хозяйстве» (18.02.1991г.), «О праве собственности на землю» (1.09.1993г.), Постановление Совета Министров Республики Беларусь «О порядке выкупа земельных участков» (4.11.1993 г.), и др., а также утративший силу Кодекс Республики Беларусь о земле 1998 г., и новый Кодекс Республики Беларусь о земле от 23 июля 2008г. № 425-3, вступивший в силу с 1 января 2009 года и другие правовые акты - создали предпосылки для развития рынка земли и появления различных форм хозяйствования на ней. Потребность в новом 
Кодексе о земле диктовалась отсутствием механизма передачи земель в аренду и определения порядка предоставления земельных участков или передачи их в собственность иностранных государств для создания на ней дипломатических и консульских учреждений. Требовалась доработка положения о том, что юридическое лицо не может приобрести землю в частную собственность. Это тормозило реальные условия развития конкуренции юридических лиц, не давало субъекту хозяйствования полного права распоряжения основным средством производства, а также лишало возможности залога земли для привлечения кредитных ресурсов и порождало многие другие проблемы экономического характера. Принятый в 1998 году Кодекс Республики Беларусь о земле определял, что земли сельскохозяйственного назначения находятся в государственной собственности. Этот постулат остается незыблемым и в новом Кодексе о земле 2008 года. Например, в США, как утверждают Р. Простерман и Р. Джиоварелли большая часть земли, в том числе 98\% возделываемых сельскохозяйственных земель, находятся в частной собственности, что избавляет правительство от бремени денежных и трудовых затрат на управление землями, позволяет местным органам власти получать доход от налогооблагаемой базы в земельной сфере, а также в результате перераспределения земля попадает к тем, кто стремится ее эффективно использовать. В 2008 году назрела необходимость принятия нового Кодекса о земле. Главное отличие нового кодекса состояло в том, что из множества прав на землю оставались и остаются только два - право собственности и право аренды. Например, предусмотрены права собственника на пожизненное домовладение, т.е. на законных основаниях владельцу будет принадлежать и земля под домом. В новом Кодексе о земле также закреплялось право на землю иностранных граждан при получении в наследство частного домовладения. С принятием нового Кодекса о земле законную силу приобретали только те сделки при наделении землей юридических и частных лиц, которые совершались через аукционы. Новый земельный кодекс 2008 года как законодательный акт послужил изначальной основой для упорядочения использования земельных ресурсов.

Земельный вопрос во многом решает состояние национальной экономики, поэтому он вызывает всевозможные экономические споры, особенно споры по внедрению. Заслуживает внимания нетрадиционная у нас трактовка собственности, которая определяется «пучком прав». Создатели данной теории - Р. Коуз, А. Алчиан, Й. Барцель, Г. Демеец, Д. Норт, Р. Познер и др.

Согласно экономической теории, такое понимание собственности на землю, отражающее поведенческие отношения между людьми по использованию относительно редкого (имеется в виду плодородие почвы) и ограниченного ресурса, а также представляющее собой систему исключений из свободного доступа к ресурсу, на наш взгляд, как нельзя лучше подходит для определения категории собственности по отношению к всеобщему средству производства - земле. Эффективное распределение земли обеспечивается четким определением прав собственности, что влечет за собой принятие хозяйствующим субъектом адекватных мер по использованию ресурса. «Если права на совершение определенных действий могут быть куплены и проданы, - пишет Р. Коуз, - их, в конце концов, приобретают те, кто выше ценит даруемые ими возможности 
производства или развлечения. В этом процессе права будут приобретены, подразделены и скомбинированы таким образом, чтобы допускаемая ими деятельность приносила доход, имеющий наивысшую рыночную ценность». Следует заметить, что степень эффективности производства сельскохозяйственной продукции земледелия не может определяться непосредственно отношениями собственности, то есть деятельностью производителей государственных или частных предприятий. Здесь решающими являются производительность труда, степень интенсификации, урожайность, культура земледелия, плодородие почвы и уровень конкуренции в отрасли.

Считаем, что было бы целесообразно официально закрепить определение собственности на землю с позиции «комплекса прав», признав землю объектом этих прав, и утвердить данное положение законодательно. Право государственной собственности будет означать, что «комплексом прав» (частично или в целом) будет обладать государство. Право частной собственности будет означать, что «комплексом прав» (частично или в целом) будут обладать физические или юридические лица. В перспективе обе формы собственности получат равноправные полномочия. Трудно не согласиться с мнением белорусского ученого А. Н. Гридюшко, который считает, что две формы собственности на землю - государственная и частная - имеют только одно принципиальное отличие - в праве владения, а правопользования и распоряжения в обоих случаях идентичны. Фактическое различие лишь в присвоении земельной ренты. В одном случае это делает общество (в лице государства), во втором - частное лицо. Границы распространения государственной формы собственности в переходной экономике подвижны, что обусловлено приватизационной политикой государства. Главной целью разгосударствления и приватизации является не формальное перераспределение собственности, а повышение эффективности производства и создание конкурентной среды, активизация инвестиционной и инновационной деятельности. Наука и практика как в Беларуси, так и за рубежом, давно признали тот факт, что само по себе введение частной собственности на землю в сельском хозяйстве автоматически не ведет к повышению его эффективности. Все формы собственности могут функционировать эффективно и иметь право на существование, если механизм их реализации многообразен и учитывает социальные, природно-экономические, духовно-нравственные, организационные, исторические и иные условия развития аграрных отношений. [9]

Немаловажное значение имеет и размер земельного участка, находящегося в частной собственности. На наш взгляд, осталась нерешенной проблема в части отмены ограничений на размер земельного участка. Размер земельного участка, согласно ст. 36 нового Кодекса о земле, предоставляемого в частную собственность, пожизненное наследуемое владение, пользование или аренду для строительства и (или) обслуживания жилого дома, обслуживания зарегистрированной организацией по государственной регистрации квартиры в блокированном жилом доме, устанавливается: в городах - от 0,05 до 0,15 гектара включительно; в населенных пунктах, расположенных в пригородных зонах г. Минска, областных центров и городов областного 
подчинения,- от 0,1 до 0,15 гектара включительно; сельских населенных пунктах, поселках городского типа- от 0,15 до 0,25 гектара включительно. Размер земельных участков, предоставляемых гражданину Республики Беларусь в сельском населенном пункте, поселке городского типа, в котором он зарегистрирован, или предоставляемых в ином населенном пункте, расположенном на территории соответствующего сельсовета, для ведения личного подсобного хозяйства в частную собственность или пожизненное наследуемое владение, не может превышать 1 гектара, а предоставляемых в аренду-4 гектаров с учетом размера земельного участка, предоставленного на территории соответствующего сельсовета для строительства и либо обслуживания жилого дома, обслуживания зарегистрированной организацией по государственной регистрации квартиры в блокированном жилом доме. Дополнительно к земельным участкам, предоставленным для ведения личного подсобного хозяйства в частную собственность или пожизненное наследуемое владение, в таких населенных пунктах в аренду могут предоставляться земельные участки, размер которых не может превышать 3 гектаров. Размер земельного участка, предоставляемого в сельском населенном пункте, поселке городского типа иностранному гражданину, лицу без гражданства, зарегистрированному по месту жительства в этом населенном пункте или ином населенном пункте, расположенном на территории соответствующего сельсовета, для ведения личного подсобного хозяйства в аренду, не может превышать 4 гектаров с учетом размера земельного участка, предоставленного в населенном пункте для строительства и (или) обслуживания жилого дома, обслуживания зарегистрированной организацией по государственной регистрации квартиры в блокированном жилом доме. Размер земельного участка, предоставляемого в частную собственность, пожизненное наследуемое владение или аренду для коллективного садоводства, дачного строительства, не может превышать 0,15 гектара на одного члена садоводческого товарищества, дачного кооператива. Размер земельного участка, предоставляемого гражданину Республики Беларусь для ведения крестьянского (фермерского) хозяйства на праве пожизненного наследуемого владения, не может превышать 100 гектаров сельскохозяйственных земель. Размер земельного участка, предоставляемого крестьянскому (фермерскому) хозяйству для ведения крестьянского (фермерского) хозяйства на праве постоянного пользования или аренды, определяется проектом отвода земельного участка. Общая площадь земельного участка, приобретаемого в частную собственность для ведения личного подсобного хозяйства, может составлять один гектар. В отличие от граждан, имеющих участки в пожизненном наследуемом владении, собственники земельных участков имеют право продавать их, дарить, сдавать в залог и аренду. Участок может быть принудительно выкуплен государством, если этого потребует государственная необходимость (залежи полезных ископаемых и т.д.), то есть существуют определенные ограничения прав землепользования и землевладения, которые носят государственно-регулируемый характер с нормативным заданием условий использования земли. На этих условиях может состояться аренда, залог, продажа земли. Граждане, имеющие земельные участки в пожизненном наследуемом владении, могут передавать их по наследству.[10]

Известно, что рынок земли определяется не только количеством проданной земли, но и 
ипотекой земельных участков, их наследованием, обменом и арендой, а также соответствующими законодательными документами, которые обеспечивают регулирование земельных отношений. Земельные отношения постоянно находятся под неукоснительным контролем законодательства, в которое систематически вносятся изменения и дополнения. Так, Законом Республики Беларусь от 22 января 2013 г. № 17-3 (Национальный правовой Интернет-портал Республики Беларусь, $25.01 .2013,2 / 2015)<$ Н1 1300017> - внесены изменения и дополнения, вступившие в силу 26 апреля 2013 г., за исключением изменений и дополнений, которые вступили в силу 1 января 2014 г. Недавний Указ № 258 от 5.06.13 г. «О внесении дополнений и изменений в Указ Президента Республики Беларусь от 27 декабря 2007 г. № 667» предусматривает обязательное возмещение потерь сельскохозяйственного и лесохозяйственного производства, вызванных изъятием или временным занятием сельскохозяйственных земель и земель лесного фонда, лицами, которым предоставляются изымаемые земельные участки. Вместо возмещения потерь землепользователь может принять на себя обязательства обеспечить в течение двух лет разработку проектно-сметной документации по освоению не используемых в сельском хозяйстве земель, площадь которых равна изымаемым, и провести работы по вовлечению этих земель в сельскохозяйственный оборот [10]. В Указе, который вступил в силу с 1 сентября 2013 года, устанавливается перечень случаев, когда подобного типа земли переводятся в другие категории, а также совершенствуется порядок предоставления земельных участков для реализации инвестиционных договоров, заключенных с Республикой Беларусь.

Все законодательные акты, связанные с земельными отношениями, направлены на более эффективное использование земель, а эффективное использование земель - это использование земель, приносящее экономический, социальный, экологический или иной полезный результат.

За время аграрного реформирования Республика Беларусь приняла немало законодательных актов и программ, позволяющих продемонстрировать не только на бумаге, но и на деле, достижения АПК. Так, по данным Белстата, зерновые и зернобобовые (в весе после доработки) увеличились с 5502 тысяч тонн в 1995 году до 9227 тысяч тонн в 2012 году, а валовой сбор сахарной свеклы увеличился за аналогичный период почти в 3,5 раза и составил в 2012 году 4774 тысяч тонн, против 1172 тысяч тонн в 1995 г. Овощей в 2012 году собрали 1581 тысяч тонн, против 1031 тысячи тонн в 1995 году. Однако картофеля в 2012 году собрали гораздо меньше, чем в 1995 году. Валовой сбор картофеля в 1995 году составлял 9504 тысячи тонн, а в 2012 году он составил всего 6911 тысяч тонн. Недобрали и по сбору льноволокна, хотя урожайность льноволокна в центнерах с гектара выросла с 6,2 до 9,0 ц/га. За время проводимой земельной реформы урожайность основных сельскохозяйственных культур имела тенденцию к повышению.[11]

В 2012 году средняя урожайность зерновых и зернобобовых по стране составила 34,5 центнера с гектара. Были предприятия, которые получали по 60 - 70 ц/га. Это неплохой результат. Если учесть, что 31 процент сельхозпродукции и 70 процентов кормов у нас выращиваются на осушенных землях, а это 3 миллиона гектаров. По заявлению директора по мелиорации и водному 
хозяйству Минсельхозпрода А. Булыни, в Беларуси будет восстановлено 107 тысяч гектаров мелиорированных земель. До конца 2015 года должны привести в порядок около 500 тысяч гектаров осушенных территорий, что будет стоить государству в 14 триллионов рублей. Вопрос об осушении болот не стоит, поскольку будет происходить только восстановление мелиорированных земель.

Медленно, но продолжалась модернизация материально-технической базы аграрного производства путем обновления машинно-тракторного парка, строительства, реконструкции и технического переоснащения производственных объектов. За последние 5 лет, по данным Белстата, энерговооруженность труда работников села увеличилась более чем на 20 процентов. В настоящее время на одного работающего в сельском хозяйстве приходится свыше 6 л.с. энергетических мощностей. Минсельхозпрод республики постоянно ориентирует сельскохозяйственное производство на инновационные механизмы развития, осуществляя в пределах своей компетенции координацию организационных и технико-технологических процессов в регионах. Работает в этом направлении и отечественная аграрная наука. Заслуга ученых заключается в том, что сегодня в стране выпускается весь шлейф сельскохозяйственных машин. В начале 90-х у нас выпускалось всего 17 процентов необходимых машин. Новая разработка «Гомсельмаша» комбайн «Полессе GS16» достаточно высокопроизводительная машина. За секунду комбайн намолачивает 16 килограммов зерна. [12]

Как отмечают белорусские ученые Л. Кукреш и П. Казакевич наряду с определенными достигнутыми успехами в аграрной отрасли, остаются ещё нерешенные экономические проблемы. Главная из них - сельскохозяйственные организации, как и в предыдущие годы, не вышли на принципы самоокупаемости и самофинансирования. Следует отметить, что в агропромышленном производстве страны есть ряд негативных явлений объективного характера. Это бедность природных ресурсов, постоянно возрастающие цены на материальные и энергетические средства, неустойчивость внешних продовольственных рынков. Вследствие государственной социальной политики, направленной на повышение доступности продуктов питания населению, ведется корректировка цен на некоторую сельскохозяйственную продукцию. Следует признать и субъективные причины, которые заключаются в недостаточном уровне профессионализма ряда руководителей и специалистов АПК, вследствие чего допускаются некоторые технологические упущения, недостатки в организации производства и в системе оплаты труда.

Тем не менее, результаты работы аграрной отрасли позволили обеспечить потребности внутреннего рынка в продовольствии, довести выручку от экспорта в 2012 году до 5 млрд. долларов США, что послужило основой для получения положительного внешнеторгового сальдо. Нельзя не сказать, что, в общем, неплохие результаты в аграрной отрасли страны являются ещё и следствием значительной государственной поддержки сельскохозяйственных организаций. 


\section{ВЫВОДЫ}

Рыночные преобразования в аграрной сфере экономики несут в себе как достижения, вызванные проведением аграрного реформирования, так и некоторые упущения в практике хозяйствования. Принятые законодательные акты, связанные с земельными отношениями, были направлены на повышение экономического плодородия земли, что выразилось в более эффективном использовании сельскохозяйственных земель, повышении урожайности возделываемых культур, совершенствовании и модернизации техники, улучшении производственной и социальной инфраструктуры села. Перед аграриями снова стоит главный вопрос: что нужно сделать для повышения эффективности АПК, обеспечения продовольственной безопасности страны, а, следовательно, и повышения благосостояния общества.

\section{ЛИТЕРАТУРА}

1. Аукционек, С. Теория переходной экономики и ее место в ряду экономических наук // С. Аукционек - Мировая экономика и международные отношения. - 1996. - № 10. - С. 11 19.

2. Государственная программа реформирования АПК Республики Беларусь (Основные направления): Одобр. Коллегией Кабинета Министров Беларуси 06.08.96г. Протокол № 13. - Мн.: Беларусь, 1996. - С. 4.

3. Кодекс Республики Беларусь о земле. 28 июля 2008 г. № 425-3// Ведомости Национального собрания Республики Беларусь. - 2009.

4. Кодекс Республики Беларусь о земле. 28 июля 2008 г. № 425-3// Ведомости Национального собрания Республики Беларусь. - 2009.

5. Официальная статистика: годовые данные // Национальный статистический комитет Республики Беларусь [Электронный ресурс]. - Минск, 2013. - Режим доступа: http://belstat.gov.by - Дата доступа: 11.06.2013.

6. Кодекс Республики Беларусь о земле. 28 июля 2008 г. № 425-3// Ведомости Национального собрания Республики Беларусь. -2009.

7. Маркс, К. Капитал. Т. 3 // К. Маркс, Ф. Энгельс. - Соч. - 2-е изд. - Т. 25, ч. II. - С. 183.

8. Гридюшко, А. Н. К вопросу о собственности на землю//А. Н. Гридюшко. - Сборник научных трудов «Проблемы» экономики». - 2012. - № 1 (14). - С. 31-37. - С.32.

9. Кодекс Республики Беларусь о земле. 28 июля 2008 г. № 425-3// Ведомости Национального собрания Республики Беларусь. - 2009.

10. Земля//Советская Белоруссия. - №102 (24237) - 6 июня 2013г.- С. 2.

11. Официальная статистика: годовые данные // Национальный статистический комитет Республики Беларусь [Электронный ресурс]. - Минск, 2013. - Режим доступа: http://belstat.gov.by - Дата доступа: 11.06.2013.

12. Хлыстун, Л. В поле сейчас хорошо/Л. Хлыстун. - Советская Белоруссия. - №102 (24237). - 6 июня 2013г.-С. 2. 